\title{
TWO HOURS OF UNINTERRUPTED MASKING: THE TOLERABILITY OF FACE MASKS AMIDST A PANDEMIC
}

\author{
Murat Eren ${ }^{1}$, Hakan Özveri ${ }^{1}$, Burak Pamukcu ${ }^{1}$, and Uzeyir Kalkan² \\ ${ }^{1}$ Acibadem University \\ ${ }^{2}$ Koc University
}

November 29, 2020

\begin{abstract}
Background/Aim: There is insufficient data on physiological and psychological alterations that may occur among health-care workers wearing various face masks during novel coronavirus-2019 (COVID-19) pandemic. In this study, we aimed to investigate the physiological effects of various types of face masking and associated discomfort among health-care workers. Methods: This prospective study included 33 healthy health-care workers. Each participant was asked to wear a single surgical mask, double mask, N95 type mask, and surgical mask on N95 type mask for an uninterrupted period of 2 hours. Oxygen saturation, heart pulse, blood pressure, respiratory rate, and step counts were recorded at baseline and every 30 min of 2 hours with a total of five times for each mask type. Self-assessment of fatigue, exhaustion, and headache were also graded. Intra- and inter-group analyses were performed. Results: There was no significant difference in the oxygen saturation, pulse and respiratory rates among the participants including intra- and inter-groups ( $\mathrm{p}>0.05)$ Although no significant difference was seen in diastolic blood pressure, systolic blood pressures gradually and significantly increased with a double surgical mask $(\mathrm{p}<0.05)$. Headache and exhaustion scores increased gradually and significantly over time at every measurement time-point with every mask type $(\mathrm{p}<0.05)$ Fatigue scores also increased in intra-group comparison of mask types without any difference in-between. Conclusion: Our study results show that, during 2 hours of period, face mask types affect only subjective parameters such as headache, exhaustion, and fatigue without any change in the objective parameters such as oxygen saturation, and pulse and respiratory rates among health-care workers.
\end{abstract}

\section{Hosted file}

mainmanuscript-IJCP_edited_final.pdf available at https://authorea.com/users/379750/articles/ 495946-two-hours-of-uninterrupted-masking-the-tolerability-of-face-masks-amidst-apandemic 


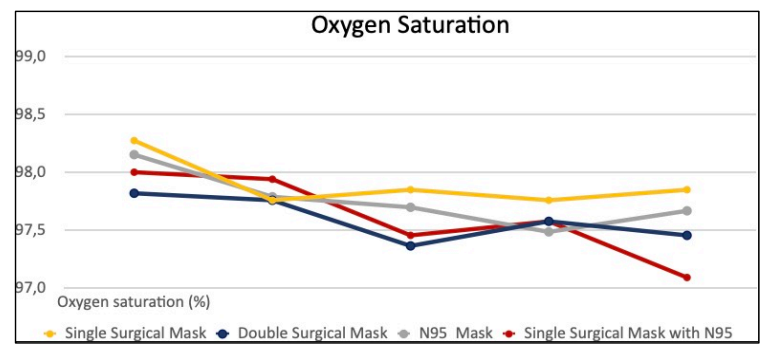




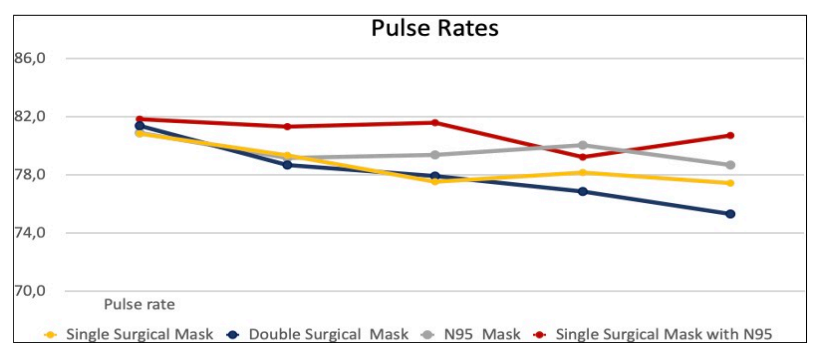




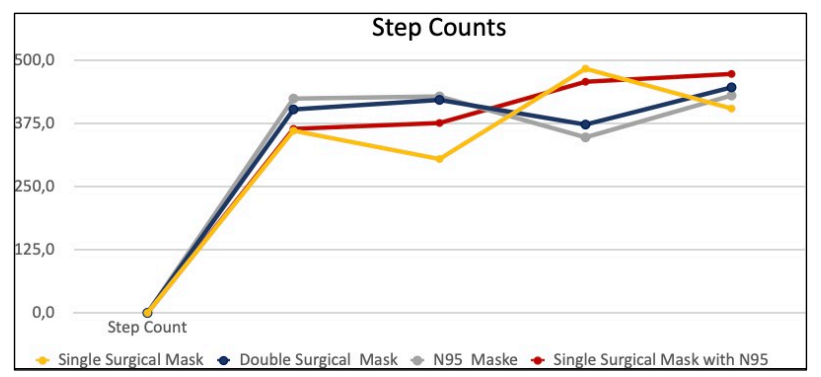




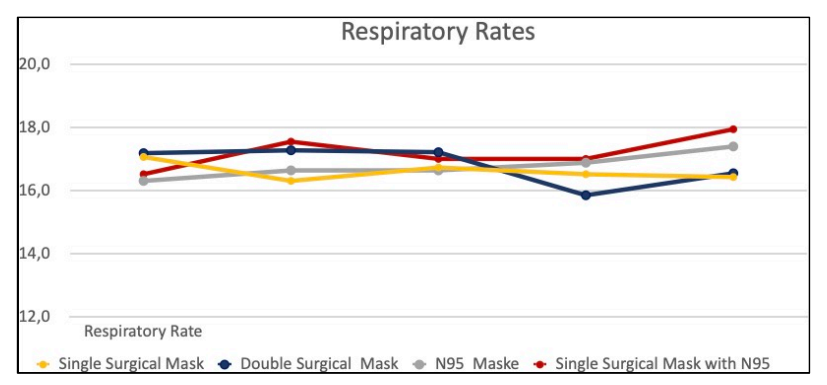




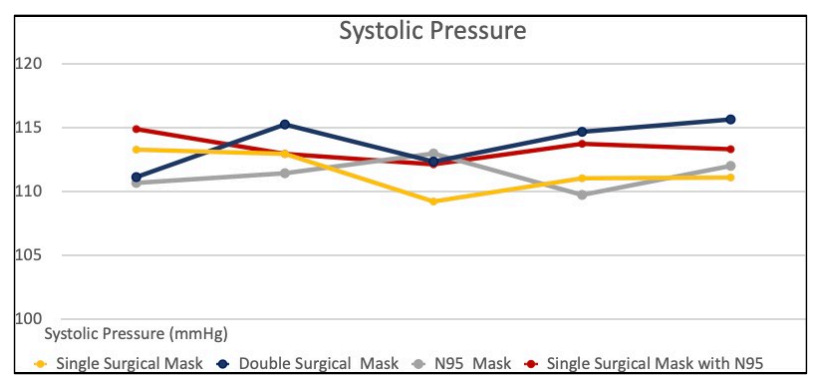




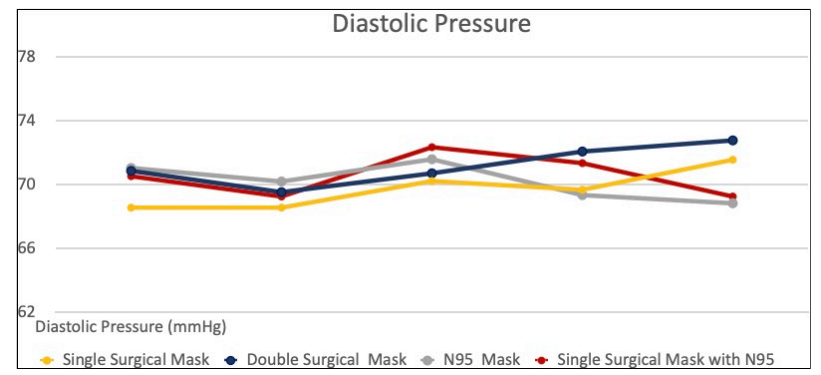

\section{Hosted file}

Table-1_IJCP.pdf available at https://authorea.com/users/379750/articles/495946-two-hoursof-uninterrupted-masking-the-tolerability-of-face-masks-amidst-a-pandemic

\section{Hosted file}

Table-2_IJCP.pdf available at https://authorea.com/users/379750/articles/495946-two-hoursof-uninterrupted-masking-the-tolerability-of-face-masks-amidst-a-pandemic

\section{Hosted file}

Table-3_IJCP.pdf available at https://authorea.com/users/379750/articles/495946-two-hoursof-uninterrupted-masking-the-tolerability-of-face-masks-amidst-a-pandemic 


\section{Hosted file}

Table-4_IJCP.pdf available at https://authorea.com/users/379750/articles/495946-two-hoursof-uninterrupted-masking-the-tolerability-of-face-masks-amidst-a-pandemic

\section{Hosted file}

Table-5_IJCP.pdf available at https://authorea.com/users/379750/articles/495946-two-hoursof-uninterrupted-masking-the-tolerability-of-face-masks-amidst-a-pandemic

\section{Hosted file}

Table-6_IJCP.pdf available at https://authorea.com/users/379750/articles/495946-two-hoursof-uninterrupted-masking-the-tolerability-of-face-masks-amidst-a-pandemic

\section{Hosted file}

Table-7_IJCP.pdf available at https://authorea.com/users/379750/articles/495946-two-hoursof-uninterrupted-masking-the-tolerability-of-face-masks-amidst-a-pandemic 